\title{
The Hepatoprotective effect of potato and Apple PEELS AS ANTIOXIDANT ON INTOXICATED RATS WITH CCL4.
}

\author{
By \\ Sello, A.A.A.EL. \\ Home Economies Dept., Faculty of Specific Education, Mansoura \\ University, Mansoura, Egypt
}

Research Gournal Specific Education

Faculty of Specific Education

Mansoura University

ISSUE NO. 22, JUL. 2011

مجلة بحوث التربية النوعية - جامعة المنصورة

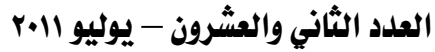




\title{
The Hepatoprotective effect of potato and Apple PeEls as ANTIOXIDANT ON INTOXICATED RATS WITH CCL4. $B y$
}

\author{
Sello, A.A.A.EL.
}

Home Economies Dept., Faculty of Specific Education, Mansoura University, Mansoura, Egypt

\section{Abstract}

The aim of this research is to evaluate potato and apple peels as a potential donor of phenolic compounds, and to study the effect of feeding dry powder of potato and apple peels, mixed with basal diet at two concentration $(10,20 \%)$, on carbon tetrachloride $(\mathrm{Ccl} 4)$ intoxicated rats for 4 weeks.

Results of this study showed that potato peel has high levels of copper $(0.826)$, calcium $(r q, r)$, copper $(\cdot, r \wedge)$ and calcium $(r \uparrow, \cdot r) \mathrm{ppm}$. Also the results revealed that total phenols content (as gallic acid \%) in potato peel was higher than apple peel (3.2 vr 2.5) respectively.

Among the test groups, total cholesterol was lowest significantly in rats group fed on $10 \%$ apple peel $(125.4 \pm 5.3 \mathrm{mg} / \mathrm{dl})$, followed by rats fed $10 \%$ potato peel $(114.6 \pm 1.32 \mathrm{mg} / \mathrm{dl})$, and rats group fed on $20 \%$ apple peel $(110.3 \pm 1.26 \mathrm{mg} / \mathrm{dl})$, while the highest decrease was noticed in rats fed on $20 \%$ potato peel $(95.7 \pm 2.3 \mathrm{mgdl})$ which differ significantly from control (+) $(152.2 \pm 10.1 \mathrm{mg} / \mathrm{dl})$.

Feeding of potato and apple peels at concentration of $20 \%$ does not show any significant values in triglycerides, HDL-cholesterol and VLDLcholesterol levels as compared to control (-) group.

The results revealed that administration of $\mathrm{Ccl} 4$ to rats leads to significant decrease in AST, ALT, uric acid and creatinine levels in the rats groups receiving the two different concentration $(10,20 \%)$ of potato and apple peels when compared to control (+) $\mathrm{Ccl} 4$ group.

Key words: Potato peel, Apple peel, Intoxicated rats, Antioxidant, phenolic compounds. 


\section{The Hepatoprotective effect of potato and Apple PEELS AS ANTIOXIDANT ON INTOXICATED RATS WITH CCL4. By} Sello, A.A.A.EL.

Home Economies Dept., Faculty of Specific Education, Mansoura University, Mansoura, Egypt

\section{Introduction}

Intake of dietary fiber and phytochemicals such as polyphenols, carotenoids, tocopherols and ascorbic acid have been related to the maintenance of health and protection from diseases such as cancer, cardiovascular diseases and many other degenerative diseases (Hertog et al., 1993, Block and Langseth, 1994, Criqui ;Ringel, 1994 and Wang and Jiao, 2000).

Peels are the major products obtained during the processing of various fruits and these were shown to be a good source of polyphenols, carotenoids and other bioactive compounds which posses various beneficial effects on human health (Larrauri, et al., 1999; Rodriguez de Sotillo, et al., 1994a and Wolfe et al., 2003).

Phenolics are widely distributed in plants where they act as attractants for certain insects, as free radical scavengers, and in defense against ultraviolet radiation, pathogens and predators (Robards et al., 1999; Treutter, 2001; Solovchenko and Schmitz- Eiberger, 2003; Hagen et al., 2007 and Petkovsek et al., 2007) .Their antioxidant properties are predominantly attributed to phenolic compounds, These compounds contain a large number of double bonds and hydroxyl groups, which generates their antioxidant activity (Lee et al.,2003 and Tsao et al.,2005).

Fruit and vegetable peels have advantages over other herbal extracts, as they are easily identifiable, commonly used by people r rich in various bioactive compounds, and some of their compounds have been characterized in terms of their chemical structures and biological properties through use of structure-activity relationship. Additionally, peels are usually considered waste, so they are obviously cost-effective (Leontowicz,et al., 2003, Parmar and Kar ,2009 and Hamendra, et al 2010). 
Potato peel, a waste by product from potato processing, could be considered as a new source of natural antioxidant. Potato peel is found to contain phenolic acids (Lisinska and Leszczynski, 1987) and recently the antioxidant activity of potato peel extract has been studied in food systems (Rodriguez de Sotillo, Hadley, Holm, 1994b). However, convincing evidence for the free radical scavenging activity of potato peel extract is still needed.

Fischer and Bipp (2005) found that potato peel sludge was recognized as a source for glucaric acid.

Flavonoids, an important class of polyphenolic of antioxidant compounds, give protection against pathogens, and herbivores (Heim et al., 2002 and Petkovsek et al., 2007). Phenolics, mainly flavonoids take part in photoadaptation and photodamage processes during fruit development. The extent of UV-B-induced damage to photosystem II of apple skin was well correlated with its quercetin glycoside content (Solovchenko and SchmitzEiberger, 2003).

Main phenolic compounds in apple peel are flavanols (epicatechins, catechins, and procyanidins), hydroxycinnamates, dihydrochalcones and anthocyanidin yanidin-3-galactoside (Mayr et al.,1995; Golding et al., 2001; Van der Sluis et al., 2001; and Kondo et al., 2002). The concentration of phenolic compounds decreases sharply in apple flesh and peel during fruit development, but phenolic content is higher in the peel than the flesh at all stages of fruit maturation (Treutter, 2001 and Renard et al., 2007).

Apples, a wide variety of which are available in many countries throughout the year, are one of the most important fruit sources of phenolics (Wolfe et al.,2008). Although apples contain different classes of bioactive compounds (Avad et al., 2000; Tsao et al., 2003; He and Liu, 2007; Lata, 2008).

The peels of apples, in particular, are high in phenolics. During applesauce and canned apple manufacture, the antioxidant-rich peels of apples are discarded. Apple peels are an abundant waste in Chilean dried products industry. This by-product has a high concentration of phenolic compounds that may assist in the prevention of chronic diseases (Valdenegro et al.,2010).

The aim of this research is to evaluate potato and apple peels as a potential donor of phenolic compounds in addition to determine their 
amounts in( ppm). This work aims also to study the effect of feeding different concentration of potato and apple peels on hepatotoxic rats injured by $\mathrm{CCl} 4$.

\section{MATERIALS AND METHODS}

\section{MATERIALS.}

\section{Samples preparation:}

\section{1 - Apple peels (Golden Delicious):}

Fresh apple peels, obtained from Best Factory, El-Dakahlia Governorate, Egypt at the end of May 2008, were washed three times with tap water and then dried at $70{ }^{\circ} \mathrm{C}$ for $5 \mathrm{~h}$ using a cross flow drier. The dried peel was powdered using a hammer mill and passed through a $0.5 \mathrm{~mm}$ sieve to obtain a fine powder. Samples were stored in freezer until use.

\section{2- Potato peels (Solanum tuberosum cv Asterix):}

Fresh potato peels, obtained from a local restaurant, El-Dakahlia Governorate, Egypt at the end of December 2008, were washed three times with tap water and then dried at $70{ }^{\circ} \mathrm{C}$ for $5 \mathrm{~h}$ using a cross flow drier. The dried peel was powdered using a hammer mill and passed through a $0.5 \mathrm{~mm}$ sieve to obtain a fine powder. Samples were stored in freezer until use.

\section{1- Rats}

Thirty five adult male white rats of Sprague Dawley strain weighing (150-180 grams). The animals were purchased from the Agricultural Research Center, Giza, Egypt.

\section{3- Induction of acute hepatitis in rats:}

Carbon tetrachloride (CCl4) an agent that is used to induced experimental acute hepatitis in rats. It was purchased from El-Gomhorya Co., Egypt in the form of $40 \%$ liquid dispensed in 1L plastic bottles.

\section{4 -Kits for biochemical analysis:}

Kits required for estimating parameters of lipid profile, liver and kidneys function were purchased from Gamma trade for pharmaceutical. 


\section{Methods:}

\section{Chemical analysis:}

Approximate chemical composition of potato and apple peels [ash, crude protein, crude fat and moisture contents] were determined according to the methods of the A.O.A.C. (2000), While total carbohydrates were estimated by subtracting the difference from initial weight of the samples as follows:-

Carbohydrates $\%=100-(\%$ moisture $+\%$ protein $+\%$ fat $+\%$ ash $)$.

\section{Determination of minerals:}

The ashed samples of potato and apple peels were dissolved in $1 \%$ hydrochloric acid and the solutions were used for the determination of the following minerals: Iron, zinc, calcium, selenium, and copper by using atomic absorption spectrophotometer [Perkins-Elmer, Model 2380] according to ( Pupsa et al., 1994)

\section{Determination of phenolic compounds.}

Phenolic compounds were determined by HPLC according to the method of (Goupy et al., 1999) at Central lab. of Food Technolpgy Research Institute Agric. Res. cent. Egypt.

\section{Scavenging effect on DPPH radicals.}

The effect of potato and apple peels on DPPH radical was studied, employing the modified method described earlier by Yamaguchi et al. (1998). Briefly, $1.5 \mathrm{ml}$ of DPPH solution $(0.1 \mathrm{mM}$, in $95 \%$ Ethanol) was incubated with varying concentrations of the extract (potato and apple peels, $0.75-5.0 \mathrm{mg}$ ). The reaction mixture was shaken well and incubated for 20 min at room temperature and the absorbance of the resulting solution was read at $517 \mathrm{~nm}$ against a blank. The radical scavenging activity was measured as a decrease in the absorbance of DPPH and was calculated using the following equation:

Scavenging effect $\%=1$ - A Sample $(517 \mathrm{~nm}) \times 100$

$$
\text { A Control (517nm) }
$$




\section{Experimental Biological Evaluation.}

\section{Animals:}

Adult male white rats weighing (150-180) were used in this study. All animal were kept under standardized conditions (12h light/ dark cycle, $22 \mathrm{oC}$ ) and were provided free access to standard diet (Table1) and water.

Table (1): Composition of the standard diet.

\begin{tabular}{|c|c|}
\hline Ingredients & g/kg diet \\
\hline \hline Casein & 200 \\
\hline Corn starch & 497 \\
\hline Sucrose & 100 \\
\hline Vitamin mixture & 020 \\
\hline Mineral mixture & 100 \\
\hline Corn oil & 050 \\
\hline Cellulose & 030 \\
\hline Methionine & 003 \\
\hline
\end{tabular}

\section{Experimental design:}

\section{Experiment:}

All rats fed the basal diet for one week before starting the experiment for acclimatization. After the acclimatization period, the rats groups which consist of thirty five rats were divided into six equal group $(\mathrm{n}=5)$ as follows:

group1: was fed on basal diet only; control (-Ve).

The other five groups were subcutaneously administered a single dose of CCl4 $(30 \% \mathrm{~V} / \mathrm{V})$ in paraffin oil $(1 \mathrm{ml} / \mathrm{kg})$ for 2 days from start of the experimental period, to induced acute hepatic damage according to the method described by Nadeen et al. (1996).

group2: was fed on the basal diet only; control $(+\mathrm{Ve})$.

group3: was fed on the basal diet containing $10 \%$ potato peel.

group4: was fed on the basal diet containing $10 \%$ apple peel.

group5: was fed on the basal diet containing $20 \%$ potato peel.

group6: was fed on the basal diet containing $20 \%$ apple peel. 


\section{Determination of body weight gain \% and feed efficiency ratio in rats:}

Daily feed intake per group was calculated through the experimental period (28). The biological values of different diets were assessed by the determination of body weight gain (BWG) and feed efficiency ratio (FER) percent, according to the method of Chapman et al. (1959).

At the end of experimental period all rats were fasted overnight then sacrificed. Blood samples were immediately collected in clean and dried Wiesserman tubes from portal vein and then centrifuged at $3000 \mathrm{rpm}$ for 15 minutes. Serum sample were separated and frozen at $-10 \mathrm{C}$ until further determination.

\section{Biochemical analysis:}

Total cholesterol, HDL-cholesterol and triglyceride content were determined by enzymatic colorimetric method according to Allian et al. (1974), Richmond (1973) and Fossati and Principle (1982), respectively.

LDL-cholesterol and VLDL-cholesterol were calculated by the Friedewald Formula according to Friedewald et al. (1972).

Plasma alanine and aspartate aminotransferase enzymes activities (ALT and AST) were determined according to the method of Reitman and Frankel (1957).

Plasma total protein was determined by an enzymatic method according to Henry (1964).

Plasma uric acid was estimated by an enzymatic method according to Trinder (1969).

Plasma creatinine was determined according to Henry (1964).

\section{Statistical analysis:}

Results of the biochemical estimations of the rats are reported as mean \pm S.E.M. (Standard deviation of Mean). The total variation was analyzed by performing one-way analysis of variance. "LSD (Least Significant Difference) test" was used for determining significance (Sümbüloglu 1998). Probability levels of less than 0.05 were considered significant. 


\section{Results and Discussion}

In this work, the nutritional value of the peel was studied in addition to studying the antioxidant activities of potato and apple peels.

\section{A-Nutritional value:}

Nutritional value of the peel was studied by determination of its content of protein, oil, ash, carbohydrates and some minerals. In addition to determination of phenolic compounds.

\section{Chemical composition of potato and apple peels samples.}

The chemical composition of the potato and apple peels are recorded in Table (2). potato peel has high level of protein and ash $(18.9 \pm 1.1 \mathrm{~g}$ and $5.3 \pm 0.93 \mathrm{~g})$ than apple peel has $(4.4 \pm 2.3 \mathrm{~g}$ and $2.5 \pm 0.11 \mathrm{~g}$ for protein and ash, respectively), while apple peel has high levels of fat and Moisture than that of potato peel $(1.7 \pm 1.75 \mathrm{~g}$ vs $0.99 \pm 0.23 \mathrm{~g}$ and $15.5 \pm 2.9 \mathrm{~g}$ vs $4.84 \pm 0.1 .6 \mathrm{~g}$ ) respectively. Data in table (2) showed that carbohydrates content of apple peel exceeded that of potato peel $(75.9 \pm 1.42$ vs $69.97 \pm 0.98$ g) per $100 \mathrm{~g}$ on dry weight basis.

Table (2): Chemical composition of potato and apple peels samples (g/100g).

\begin{tabular}{|c|c|c||}
\hline Variables & Potato peel & Apple peel \\
\hline \hline Protein & $18.9 \pm 1.1$ & $4.4 \pm 2.3$ \\
\hline Fat & $0.99 \pm 0.23$ & $1.7 \pm 1.75$ \\
\hline Ash & $5.3 \pm 0.93$ & $2.5 \pm 0.11$ \\
\hline Moisture & $4.84 \pm 0.1 .6$ & $15.5 \pm 2.9$ \\
\hline Carbohydrate & $69.97 \pm 0.98$ & $75.9 \pm 1.42$ \\
\hline
\end{tabular}

\section{Mineral content of potato and apple peels (ppm).}

The results in Table (3) showed that potato peel has high levels of copper $(0.826)$ and calcium $(\uparrow q, r)$ ppm than apple peel $(\cdot, \uparrow \wedge$ ppm for copper) and $(r \uparrow, \cdot r$ ppm for calcium). Concerning zinc and iron, it was found that apple peel has high levels than that of potato peel $\left(\cdot, 0 \mathrm{~V}\right.$ Vs, , o $r$ and $r_{\cdot, \tau} \mathrm{Vs}$ $1 \wedge, 7$ ) ppm, respectively.

The peels of apples have also been recommended as part of an antiatherosclerotic diet due to their rich amounts of total, soluble, and insoluble dietary fiber, total phenols, epicatechin, and gallic and p-coumaric 
acids along with concentrations of $\mathrm{Na}, \mathrm{K}, \mathrm{Mg}, \mathrm{Ca}, \mathrm{Fe}$, and $\mathrm{Mn}$ (Gorinstein,et al., 2001).

Table (3): Mineral content of potato and apple peels (ppm).

\begin{tabular}{|c|c|c|}
\hline Minerals & Potato peel & Apple peel \\
\hline Zinc(ppm) &., $0 Y$ & $\cdot, 07$ \\
\hline Copper(ppm) & $\cdot, \wedge r T$ & $\cdot, \uparrow \wedge$ \\
\hline Calcium(ppm) & $r q, r$ & $r 7, \cdot r$ \\
\hline Iron (ppm) & 11,7 & $r \cdot, T$ \\
\hline Selenium (ppm) &., .1 &., .1 \\
\hline
\end{tabular}

\section{Phenolic acids of potato and apple peels.}

Polyphenolic compounds are very important fruit constituents, by virtue of their antioxidant activity by chelating redox- active meta ions, inactivating lipid free radical chains and preventing hydroperoxide.

The main phenolic acids identified in potato and apple peels are presented in Table (4).The results showed that potato peel has higher contents of Catechin, Benzoic, Caffiec and Chrisin than apple peel (38.36 vr $37.22,12.78$ vr 9.62, $44.23 \mathrm{vr}--$ and $3.34 \mathrm{vr}--)$ respectively. While apple peel has higher content of Vanillic, Synergic, Caffeine, Coumaric, Salicylic, Ferrulic and Nariginin than potato peel (78.91 vr 3.95, $6.73 \mathrm{vr}--, 3.55 \mathrm{v} \mathrm{r}--$ , $6.04 \mathrm{vr} 3.18,80.19 \mathrm{vr} 7.87,12.25 \mathrm{vr}-$ and $17.32 \mathrm{vr} 13.48)$ respectively. Data in Table (4) showed that total phenol (\%) as gallic acid in potato peel was higher than apple peel (3.2 vr 2.5).

The peel expresses a significantly higher concentration of phenolics compared to the flesh ( Alonso -Salces et al., 2004; McGhie et al., 2005; Veberic et al., 2005; Petkovsek et al.,2007; Drogoudi et al.,2008).

Potato peel extract had the highest antioxidant activity owing to its high content of phenolic compounds and flavonoids ( Sarhan et al, 2010).

Onyencho and Hettiarachchy (1993) indicated that petroleum ether extract of potato peels showed strong antioxidant activity due to the presence of chlorogenic, gallic, cinnamic and ferulic acids as the major antioxidant compounds in the extract.

Nandita and Rajini (2004) showed that, The total polyphenolic content in potato peel extract PPE was found to be $3.93 \mathrm{mg} / \mathrm{g}$ powder. The 
major phenolic acids present in PPE were predominantly: gallic acid, caffeic acid, chlorogenic acid and protocatechuic acid .

Apple peels were found to contain up to $3300 \mathrm{mg} / 100 \mathrm{~g}$ dry weight of phenolics (Wolfe and liu, 2003). Apple peel displays a large amount of antioxidant properties ( Eberhardt et al., 2000; Wolfe et al., 2003 and Tsao et al., 2005).

Table (4) Phenolic acids of potato and apple peels (ppm).

\begin{tabular}{|c|c|c|}
\hline \multirow{2}{*}{ Phenolic compounds } & \multicolumn{2}{|c|}{ Test Results } \\
\hline & Potato peel & Apple peel \\
\hline Catechin & 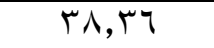 & TV,YY \\
\hline Vanillic & $r, 90$ & $\vee \wedge, 91$ \\
\hline Synergic & ------ & $7, V \pi$ \\
\hline P.OH Benzoic & $M, V \lambda$ & 9,74 \\
\hline Caffeine & $\begin{array}{ll}--- \\
---\end{array}$ & $r, 00$ \\
\hline Coumaric & $r, 1 \wedge$ & $7, \cdot \varepsilon$ \\
\hline Salicylic & $\vee, \wedge \vee$ & $\Lambda \cdot, 19$ \\
\hline Ferrulic & ------ & IT,YO \\
\hline Nariginin & $1 \Gamma, \varepsilon \wedge$ & IV,Y \\
\hline Cinnamic acid & $\cdot, \wedge \wedge$ & $\cdot, \mathrm{VY}$ \\
\hline Caffiec & $\varepsilon \varepsilon, Y T$ & ---- \\
\hline Chrisin & $r, \Gamma \leqslant$ & $\begin{array}{ll}--- \\
---\end{array}$ \\
\hline Total Phenol (\%) as gallic acid & $r, Y$ & $r, 0$ \\
\hline
\end{tabular}

\section{B) Antioxidants activity of potato and apple peels extract.}

\section{1- Scavenging effect on DPPH radicals.}

DPPH radical scavenging abilities of potato and apple peels extract along with the reference antioxidant BHT( butylated hydroxy toluene) are shown in Table (5) and expressed as percentage reduction, the scavenging activity of potato peel at concentration of $500 \mathrm{ul} / \mathrm{ml}$ was $93.4 \pm 1.4 \%$ followed by BHT $91.4 \pm 1.8 \%$ then apple peel $86.5 \pm 5.1 \%$.

In addition at concentration of $250 \mathrm{ul} / \mathrm{ml}$, the results revealed that the potato peel was the excellent radical scavenger with $82.63 \pm 3.1 \%$ followed by BHT with value of $77.6 \pm 2.2 \%$ then apple peel $74.03 \pm 2.06 \%$. 
The results also showed that potato peel was the best radical scavenger with74.46 $\pm 1.2 \%$ followed by BHT $72.53 \pm 6.07 \%$ then apple peel $55.96 \pm 2.9 \%$ at concentration of $200 \mathrm{ul} / \mathrm{ml}$.

Besides, a concentration of $100 \mathrm{ul} / \mathrm{ml}$ was the best radical scavenger with a value of potato peel $(62.73 \pm 1.6 \%)$ followed by the value of BHT $(48.53 \pm 6.51 \%)$ then apple peel $(32.86 \pm 4.1)$.

However, convincing evidence for the free radical scavenging activity of potato peel extract is still needed, Nandita and Rajini (2003) studied that antioxidant activity of PPE، employing in vitro assay systems, such as inhibition of lipid peroxidation, DPPH/superoxide/hydroxyl radical scavenging, and iron ion chelation, in order to understand the mechanisms of its antioxidative activity.

Chemical structure of phenolics makes them ideal as antioxidant compounds, free radical scavengers and metal chelators, more powerful as compared to vitamin C (Rice-Evans et al., 1997 and Guo et al., 2003).

The peel has substantially higher phytochemical content and greater antioxidant activity ( Łata et al., 2009). These antioxidants obtained from potato have free radical scavenging effects ( Singh et al., 2011).

\section{Table (5): Scavenging effect (\%) of potato and apple peels on (DPPH)} radical.

\begin{tabular}{||c|c|c|c||}
\hline & \multicolumn{1}{|l|}{ BHT } & Potato peel & Apple peel \\
\hline \hline $100 \mathrm{Ul} / \mathrm{ml}$ & $48.53 \pm 6.51$ & $62.73 \pm 1.6$ & $32.86 \pm 4.1$ \\
\hline $200 \mathrm{ul} / \mathrm{ml}$ & $72.53 \pm 6.07$ & $74.46 \pm 1.2$ & $55.96 \pm 2.9$ \\
\hline $250 \mathrm{ul} / \mathrm{ml}$ & $77.6 \pm 2.2$ & $82.63 \pm 3.1$ & $74.03 \pm 2.06$ \\
\hline $500 \mathrm{ul} / \mathrm{ml}$ & $91.4 \pm 1.8$ & $93.4 \pm 1.4$ & $86.5 \pm 5.1$ \\
\hline
\end{tabular}

Each value is the Mean \pm SD.

\section{C) Biological results.}

Effect of feeding different concentration of potato and apple peels on daily feed intake, body weight gain, and food efficiency ratio in toxicated rats.

A significant decreases of daily food intake, body weight gain and food efficiency ratio were noticed in control $(+)$ group when compared to all experimental groups administered $\mathrm{CCl} 4$. 
Feeding on potato and apple peels powder to $\mathrm{CCl} 4$ intoxicated rats at concentration of 10 and $20 \%$ increase significantly daily food intake when compared to control (+) group, while rats groups fed on $10 \%$ potato and apple peels have daily food intake values of $(11.44 \pm 0.46 \mathrm{~g} / \mathrm{day})$ and (10.66 $\pm 0.66 \mathrm{~g} /$ day) which were not significant when compared to control (-) group (11.36+0.77 g/day) as shown in Table (6).

Concerning body weight gain (BWG) percent, administration of $\mathrm{Ccl} 4$ revealed significant decrease in $\mathrm{BWG} \%$ in control $(+)$ group when compared to the treatment groups. Data in Table (6) shows that the highest significantly in (BWG\%) was seen in rats group fed on $20 \%$ potato peel $(63.23 \pm 2.05)$, followed by rats group fed on $20 \%$ apple peel $(59.1 \pm 1.1)$, when compared with control (+) group $(24.13 \pm 1.04)$.

The intake of caffic acid from foods, mainly from tomatoes or potatoes was estimated to be about $0.2 \mathrm{mg} / \mathrm{kg}$ body weight per day (National research council 1996).

On the other hand, the results showed that food efficiency ratio of $\mathrm{CCl} 4$ intoxicated rats control $(+)(0.153 \pm 0.05)$ decrease significantly in comparing with control (-) group $(0.27 \pm 0.064)$, rats group fed on $10,20 \%$ potato peels and $10,20 \%$ apple peels $(0.18 \underline{ \pm 0.2}, 0.24 \pm 0.4,0.176$ and $0.19 \pm 1.5)$ respectively.

Table (6): Effect of feeding different concentration of potato and apple peels on daily feed intake (g/day), body weight gain percent (BWG \%), and feed efficiency ratio (FER) in hepatotoxic rats.

\begin{tabular}{||c|c|c|c||}
\hline Group & $\begin{array}{c}\text { Mean of daily food } \\
\text { intake (g/day) }\end{array}$ & $\begin{array}{c}\text { Body weight } \\
\text { gain (BWG \% })\end{array}$ & $\begin{array}{c}\text { Food efficiency } \\
\text { ratio }\end{array}$ \\
\hline Control(-)Ve & $11.36 \pm 0.77 \mathrm{da}$ & $54.96 \pm 0.41 \mathrm{a}$ & $0.27 \pm 0.064 \mathrm{a}$ \\
\hline Control(+)VeCcl4 & $8.8 \pm 0.65 \mathrm{~b}$ & $24.13 \pm 1.04 \mathrm{~b}$ & $0.153 \pm 0.05 \mathrm{~b}$ \\
\hline $10 \%$ potato peel & $11.44 \pm 0.46 \mathrm{da}$ & $49.83 \pm 0.94 \mathrm{bd}$ & $0.18 \pm 0.2 \mathrm{c}$ \\
\hline $20 \%$ potato peel & $13.33 \pm 0.28 \mathrm{c}$ & $63.23 \pm 2.05 \mathrm{ea}$ & $0.24 \pm 0.4 \mathrm{~d}$ \\
\hline $10 \%$ apple peel & $10.66 \pm 0.66 \mathrm{a}$ & $33.36 \pm 2.01 \mathrm{bc}$ & $0.176 \pm 0.0 \mathrm{e}$ \\
\hline $20 \%$ apple peel & $12.1 \pm 0.77 \mathrm{~d}$ & $59.1 \pm 1.1 \mathrm{be}$ & $0.19 \pm 1.5 \mathrm{f}$ \\
\hline
\end{tabular}

Each value is the mean + SD of 5 rats.

The values in the column with the same superscript are not significant different at $P<0.05$. 


\section{Effect of feeding potato and apple peels powder on serum constituents in hepatotoxic rats.}

Data in Table (7) revealed that administration of $\mathrm{CCl} 4$ to rats leads to significant decrease in serum total cholesterol, triglyceride, LDLcholesterol and VLDL- cholesterol levels than those of control (+)Ve Ccl4.

Among the test group, total cholesterol decreased significantly in all the treated rats whereas the least increase was found in the group fed on $10 \%$ apple peel $(125.4 \pm 5.3 \mathrm{mg} / \mathrm{dl})$, followed by rats group fed on $10 \%$ potato peel $(114.6 \pm 1.32 \mathrm{mg} / \mathrm{dl})$, and the group fed on $20 \%$ apple peel $(110.3$ $\pm 1.26 \mathrm{mg} / \mathrm{dl}$ ), while the highest decrease was in rats fed on $20 \%$ potato peel $(95.7 \pm 2.3 \mathrm{mgdl}) \quad$ which differ significantly from control (+) $(152.2 \pm 10.1 \mathrm{mg} / \mathrm{dl})$.

These results agreed with that of Lazaroy and Werman (1996), they found that after four weeks, the rats fed on potato peel showed a $40 \%$ decrease in plasma cholesterol content and a reduction of $30 \%$ in hepatic fat cholesterol level.

Results in Table(7), indicated that all the test groups either control(-) or rats groups fed on potato peel 10 and $20 \%$ and rats groups fed on apple peel 10and $20 \%$ revealed significant decrease in triglycerides, LDLcholesterol and VLDL-cholesterol levels in comparing with that of control (+) $\mathrm{CCl} 4$ group.

The highest reduction percentages in triglycerides, LDL-cholesterol and VLDL- cholesterol levels were noticed in the rats group receiving 20\% potato peel $(50.95,82.82$ and $49.82 \%)$ respectively, followed by rats group receiving $20 \%$ apple peel $(46.38,59.3$, and $47.4 \%)$ respectively, followed by rats group receiving $10 \%$ potato peel $(30.72,50.1$, and $39.3 \%$ ) respectively, while the lowest reduction percentage in rats receiving $10 \%$ apple peel were $(18.93,32$, and $18.99 \%)$ respectively.

Feeding of $20 \%$ potato peel recorded non significant values in total cholesterol and LDL- cholesterol levels when compared to control (-) group as shown in Table (7).

On the other hand, significant increase in HDL-cholesterol level of rats receiving $20 \%$ potato peel $(69.8 \pm 2.4 \mathrm{mg} / \mathrm{dl})$ was noticed when compared to control (+) group $(42.2 \pm 1.7 \mathrm{mg} / \mathrm{dl})$, rats receiving $10 \%$ potato 
peel $(57.4 \pm 1.6 \mathrm{mg} / \mathrm{dl})$, rats receiving $10 \%$ apple peel $(48.1 \pm 7.4 \mathrm{mg} / \mathrm{dl})$ and rats receiving $20 \%$ apple peel $(62.9 \pm 3.1 \mathrm{mg} / \mathrm{dl})$.

Feeding of potato and apple peels at concentration of $20 \%$ showed non significant differences in triglycerides, HDL-cholesterol and VLDLcholesterol levels when compared to control (-) group as shown in table (7). Apple peels is also reported to have antioxidative potential according to various in vitro methods such as total radical-trapping antioxidative potential values, which also correlate with their polyphenolic conten. Peels of fruits have also been found to be antiperoxidative in hypercholesterolemic diet-fed animals (Leontowicz, et al., 2002, Hamendra, et al., 2010) .

So it is advised by using potato and apple without removing peel to the patients with hyperlipidemia or those exposed to atherosclerosis.

Table (7): Effect of feeding potato and apple peels powder on serum lipids pattern in toxicated rats.

\begin{tabular}{||c|c|c|c|c|c||}
\hline \hline Group & $\begin{array}{c}\text { Cholesterol } \\
(\mathbf{m g} / \mathbf{d l})\end{array}$ & $\begin{array}{c}\text { Triglyceride } \\
\mathbf{s}(\mathbf{m g} / \mathbf{d l})\end{array}$ & $\begin{array}{c}\text { HDL- } \\
\mathbf{c}(\mathbf{m g} / \mathbf{d l})\end{array}$ & $\begin{array}{c}\text { LDL-c } \\
(\mathbf{m g} / \mathbf{d l})\end{array}$ & $\begin{array}{c}\text { VLDL-c } \\
(\mathbf{m g} / \mathbf{d l})\end{array}$ \\
\hline \hline Control(-)Ve & $94.86 \pm 1.66 \mathrm{a}$ & $54.7 \pm 1.83 \mathrm{a}$ & $67.3 \pm 2.35 \mathrm{ae}$ & $19.6 \pm 8.4 \mathrm{a}$ & $11.02 \pm 0.58 \mathrm{a}$ \\
\hline Control(+)VeCcl4 & $152.2 \pm 10.1 \mathrm{~b}$ & $110.23 \pm 3.85 \mathrm{~b}$ & $42.4 \pm 1.7 \mathrm{~b}$ & $87.7 \pm 9.1 \mathrm{~b}$ & $22.06 \pm 0.7 \mathrm{~b}$ \\
\hline 10\% potato peel & $114.6 \pm 1.32 \mathrm{ed}$ & $67.36 \pm 7.12 \mathrm{~d}$ & $57.4 \pm 1.6 \mathrm{~d}$ & $43.76 \pm 2.72 \mathrm{~d}$ & $13.4 \pm 1.4 \mathrm{~d}$ \\
\hline 20\% potato peel & $95.7 \pm 2.3 \mathrm{a}$ & $54.06 \pm 1.67 \mathrm{a}$ & $69.8 \pm 2.4 \mathrm{e}$ & $15.06 \pm 0.77 \mathrm{a}$ & $10.8 \pm 0.34 \mathrm{a}$ \\
\hline $10 \%$ apple peel & $125.4 \pm 5.3 \mathrm{c}$ & $89.36 \pm 0.66 \mathrm{c}$ & $48.1 \pm 7.4 \mathrm{bc}$ & $59.6 \pm 7.1 \mathrm{c}$ & $17.87 \pm 0.13 \mathrm{c}$ \\
\hline 20\% apple peel & $110.3 \pm 1.26 \mathrm{e}$ & $59.1 \pm 1.05 \mathrm{a}$ & $62.9 \pm 3.1 \mathrm{da}$ & $35.7 \pm 4.3 \mathrm{de}$ & $11.62 \pm 0.39 \mathrm{a}$ \\
\hline
\end{tabular}

Each value is the mean + SD of 5 rats.

The values in the column with the same superscript are not significant different at $\mathrm{P}<0.05$.

Effect of feeding potato and apple peels powder on serum levels of $\operatorname{AST}(\mathrm{U} / \mathrm{L})$, ALT $(\mathrm{U} / \mathrm{L}))$, uric acid $(\mathrm{mg} / \mathrm{dl})$ and creatinine $(\mathrm{mg} / \mathrm{dl})$ in toxicated rats.

Data in Table (8) revealed that administration of $\mathrm{CCl} 4$ to rats lead to significant decrease in AST, ALT, uric acid and creatinine levels in the rats groups receiving the two different concentration (10,20\%) of potato and apple peels when compared to control (+) $\mathrm{CCl} 4$ group.

Results in Table (8), indicated that all test groups have significant decrease in AST level where its value in the rats receiving $20 \%$ potato peel 
was $25.3 \pm 5.2 \mathrm{u} / \mathrm{l}$, in rats group receiving $20 \%$ Apple peel $(39.3 \pm 5.7 \mathrm{u} / \mathrm{l})$, in rats group receiving $10 \%$ potato peel $(51.46 \pm 3.9 \mathrm{u} / 1)$ and rats group receiving $10 \%$ apple peel $(68.83+3.35 \mathrm{u} / \mathrm{l})$ when compared to control $(+)$ group $(79.96 \pm 3.1 \mathrm{u} / 1)$.

Data presented in Table (8) revealed a significant increase in ALT level of control (+) $\mathrm{CCl} 4$ group when compared to all groups. The lowest decrease was seen in the group receiving $20 \%$ potato peel $(33.26 \pm 0.9 \mathrm{u} / \mathrm{l})$ which was more than that of control (-) group $(31.93 \pm 0.55 \mathrm{u} / 1)$ and less than that of group receiving $20 \%$ apple peel $(39.36 \pm 1.25 \mathrm{u} / \mathrm{l})$.

It is well known that carbon tetrachloride $\mathrm{CCl} 4$ has been widely used in animal models to investigate chemical toxin-induced liver injury (Lee. et al., 2005). The CCl4 produced damage to liver cells and was followed by the significant increase in serum alanine aminotransferase (ALT) activity and hepatic lipid peroxidation after $24 \mathrm{~h}$. Increased lipid peroxidation is a mechanism which is commonly suggested to explain the progression of liver damage and the development of fibrosis, and eventually cirrhosis in experimental animals and in alcoholic liver disease (Goldani et al., 2007).

Major phenolic compounds have been reported to exert free radical scavenging and anti- peroxidative effect in liver microsomes, hepatocytes and erythrocytes (Liu et al., 1992).

Feeding of $20 \%$ potato peel did not record any significant differences in AST, ALT and creatinine when compared to control (-) group as shown in table (8).

Data in Table (8) shows that uric acid and creatinine increase significantly in control (+) group $(6.96 \pm 0.95$ and $2 \pm 0.1 \mathrm{mg} / \mathrm{dl})$ respectively, when compared to all group.

Peel extract not only quenches DPPH radicals but also lowers hepatic lipid peroxidation values induced by CCl4 and $\mathrm{H} 2 \mathrm{O} 2$ ( Dixit, et al., 2008).

Feeding of potato and apple peels at concentration of $20 \%$ did not record any significant differences in uric acid when compared to control (-) group as shown in Table (8). 
Table (8): Effect of feeding potato and apple peels powder on serum levels of AST (U/L), ALT (U/L)), uric acid (mg/dl) and creatinine $(\mathrm{mg} / \mathrm{dl})$ in toxicated rats.

\begin{tabular}{||c|c|c|c|c||}
\hline Group & AST $(\mathbf{U} / \mathbf{L})$ & ALT $(\mathbf{U} / \mathbf{L})$ & $\begin{array}{c}\text { Uric acid } \\
(\mathbf{m g} / \mathbf{d l})\end{array}$ & $\begin{array}{c}\text { Creatinine } \\
(\mathbf{m g} / \mathbf{d l})\end{array}$ \\
\hline \hline Control(-)Ve & $27.63 \pm 5.48 \mathrm{a}$ & $31.93 \pm 0.55 \mathrm{a}$ & $2.1 \pm 0.22 \mathrm{ad}$ & $0.53 \pm 0.66 \mathrm{a}$ \\
\hline Control(+)VeCcl4 & $79.96 \pm 3.1 \mathrm{~b}$ & $56.1 \pm 0.9 \mathrm{~b}$ & $6.96 \pm .95 \mathrm{~b}$ & $2 \pm 0.1 \mathrm{~b}$ \\
\hline $10 \%$ potato peel & $51.46 \pm 3.9 \mathrm{~d}$ & $43.23 \pm 0.98 \mathrm{~d}$ & $2.73 \pm 2.1 \mathrm{ac}$ & $1.13 \pm 0.15 \mathrm{~d}$ \\
\hline $20 \%$ potato peel & $25.3 \pm 5.2 \mathrm{a}$ & $33.26 \pm 0.9 \mathrm{a}$ & $2 \pm 4.1 \mathrm{~d}$ & $0.53 \pm 1.1 \mathrm{a}$ \\
\hline $10 \%$ apple peel & $68.83 \pm 3.35 \mathrm{c}$ & $46 \pm 11.15 \mathrm{c}$ & $3.06 \pm 0.15 \mathrm{c}$ & $1.73 \pm 2.1 \mathrm{c}$ \\
\hline $20 \%$ apple peel & $39.3 \pm 5.7 \mathrm{e}$ & $39.36 \pm 1.25 \mathrm{e}$ & $2.4 \pm 1.3 \mathrm{dac}$ & $0.73 \pm 1.4 \mathrm{e}$ \\
\hline
\end{tabular}

Each value is the mean $+\mathrm{SD}$ of 5 rats.

The values in the column with the same superscript are not significant different at $\mathrm{P}<0.05$.

\section{Conclusion}

In the present study, Phenolic compounds are ubiquitous in plants as potato and apple peels when are consumed; these phytochemicals contribute to the intake of natural antioxidants. So the health benefits of potato and apple peels are largely due to the antioxidant and the large number of phytochemicals,

So it is advised by using potato and apple without removing peel to the patients with hyperlipidemia or those exposed to atherosclerosis and can protect the injury of liver. .

Therefore, it is suggested that further work utilizing of potato and apple peels as source of phenolic compounds could offer diverse opportunities for nutraceutical and functional food applications and could be performed on the isolation and identification of the main components in potato and apple peels to be used in drugs and food preservatives. 


\section{References}

A O A C., 2000: Association of Official Agricultural Chemists. Official Method of Analysis. $17^{\text {th }}$ Ed. Vol. 11. Washington U.S

Allian, C.A.; Poon, S.; Chan, C. S. G. Richmond, W. and Fu, P.C., 1974: Enzymatic determination of total serum cholesterol. Clinical Chemistry 20:470-475.

Alonso-Salces, R. M., Barranco, A., Abad, B., Berrueta, L. A., Gallo, B., and Vicente, F., 2004: Polyphenolic profiles of basque cider apple cultivars and their technological properties. J. Agric. Food Chem. 52, 2938 - 2952.

Avad, M.A.,de Jager, A., and van Westing,L.M., 2000: Flavonoid and chlorogenic acid levels in apple fruit: characterization of variation. Sci. Hort.83, 249 - 263.

Block, G. and Langseth, L. 1994: Antioxidant vitamins and disease prevention, Food Technology 48: 80-84.

Chapman, D. G., Castilla, R. and Campbell, J. A., 1959: Evaluation of protein in food. Determination of protein and food efficiency ratio. Can. J. Biochem. and physil., 37:679-686.

Criqui, M.H. and Ringel, B.L., 1994: Does diet or alcohol explain the French paradox?, Lancet 344: 1719-1723.

Dixit, Y., Panda, S., and Kar, A., 2008: Lagenaria siceraria peel extract in the regulation of hyperthyroidism, hyperglycemia and lipid peroxidation in mice. Int J Biomed Pharma Sci,. 2:79-83.

Drogoudi, P. D., Michailidis, Z., and Pantelidis, G., 2008: Peel and. esh antioxidant Content and harvest quality characteristics of seven apple cultivars. Sci. Hort. 115,149 -153.

Eberhardt, M.V., Lee, C.Y., and Liu, R.H., 2000: Antioxidant activity of fresh apples. Nature $903-904$.

Fischer, K. and Bipp, H.P. 2005: Generation of organic acids and monosaccharides by hydrolytic and oxidative transformation of food processing residues. Bioresource Technology. 96 (7): 831-842.

Fossati, P. and Principle, L. 1982: Estimation of the concentration of triglyceride in plasma and liver. Clinical Chemistry 28: 2077- 2081.

Friedewald, W.T.; Levy, R.I. and Fredriek-Son, D.S., 1972: Estimation of concentration of low-density lipoproteins separated by three different methods. Clin. Chem. 28:2077.

Goldani, H. A. S.; Matte, U. S.; Ramos, A. R. L؟. Costa, T. G.; Winkelmann, L. V.; Meurerc, L؟. Vieiraa, S. M. G.; Kielinga, C. O. and Silveira, T. R., 2007: The role of food restriction on CCl4- induced cirrhosis model in rats. Experimental and Toxicologic Pathology, 58: 331-337. 
Golding, J .B., McGlasson,W.B.,Wyllie, S. G.,and Leach, D. N., 2001: Fate of apple peel phenolics during cool storage. J. Agric. Food Chem.49, $2283,2289$.

Gorinstein, S., Zachwieja, Z., Folta, M., Barton, H., Piotrowicz, J., Zemser, M., Weisz, M., Trakhtenberg, S., and Màrtín-Belloso, O., 2001: Comparative contents of dietary fiber' total phenolics, and minerals in persimmons and apples. J Agric Food Chem. 49:952-957.

Goupy, P: Hugues M., Boivin, P and Amiot, j., 1999: Antioxidant composition and activity of barley (Hordeum vulgare) and malt extract and of isolated phenolic compunds. J.Sci. Food Agric.79: 1625-1634.

Guo,C., Yang,J.,Wei, J., Li,Y., Xu, J., and Jiang,Y., 2003: Antioxidant activities of peel, pulp and seed fractions of common fruits as determined by FRAP assay. Nutr. Res. 23, 1719 - 1726.

Hagen, S. F., Bore, G.I.A., Bengtsson, G. B., Bilger, W., Berge, A., Haffner,K., and Solhaug, K. A., 2007: Phenolic contents and others health and sensory related properties of apple fruit (Malus domestica Borkh.,cv.Aroma):effect of postharvest UV-B irradiation.Postharvest Biol.Technol.45,1 -10.

Hamendra, S. P., Yamini, D., and Anand Kar 2010: Fruit and vegetable peels: Paving the way towards the development of new generation therapeutics, Drug Discoveries \& Therapeutics. 4(5):314-325.

He, X., and Liu, R. H., 2007: Triterpenoids isolated from apple peels have potent antiproliferative activity and may be partially responsible for apple anticancer activity. J. Agric. Food Chem. 55, 4366 - 4370.

Heim, K. E., Tagliaferro, A. R., and Bobilya, D.J., 2002: Flavonoid antioxidant:chemistry, metabolism and structure, ctivity relationships. J. Nutr. Biochem.13, 572 - 584. .

Henry, R. J., 1964: Clinical chemistry, Harper and row publishers New York, 181. Henry, R.J.1974: Clinical chemistry, Principles and technis $2^{\text {nd }}$ Edition Harper and row 525.

Hertog, M. M., Feskens, E. J., Hollman, P., C., Katan, M., B., and Kromhout, D., 1993: Dietry antioxidant flavonoids and risk of cornary heart disease: the Zutphen Eldery study. Lancet, 342, 1007-1011.

Kondo, S., Tsuda, K., Muto, N., and Ueda, J., 2002: Antioxidative activity of apple skin or .esh extracts associated with fruit development of selected apples cultivars.Sci.Hort.96,177,185.

Larrauri, J. A., Rupe’ rez, P., Borroto, B., and Saura-Calixto, F., 1999: Mango peels as a new tropical .bre: preparation and characterization. Lebensmittel-Wissenschaft and Technologie, 29, 729-733.

Lata B., Trampczynska A., and Paczesna J., 2009: Cultivar variation in apple peel and whole fruit phenolic composition, Scientia Horticulturae 121, 176-181. 
Lata, B., 2008: Apple peel antioxidant status in relation to genotype, storage type and time. Sci. Hort, 117,45-52.

Lazaroy, K. and Werman, M.J. 1996: Hypocholesterolaemic effect of potato peels as a dietary fiber source. Med. Sci. Res. 24: 581-582.

Lee, G.P., Jeong, W.I., Jeong, D.H., Do, S.H‘. Kim, T.H and Jeong, K.S., 2005: Diagnostic evaluation of carbon tetrachloride-induced rat hepatic cirrhosis model. Anticancer Res. Mar-Apr؛ 25(2A):1029-38.

Lee, K. W., Kim, Y. J., Kim, D., Lee, H. J., and Lee, C. Y., 2003: Major phenolics in apple and their contribution to the total antioxidant capacity. J. Agric. Food Chem.51, 6516 - 6520.

Leontowicz, H., Gorinstein, S., Lojek, A., Leontowicz, M., Cíz, M., Soliva Fortuny, R., Park, Y.S. ,Jung, S.T., Trakhtenberg, S., and MartinBelloso, O., 2002: Comparative content of some bioactive compounds in apples, peaches and pears and their influence on lipids and antioxidants capacity in rats. J Nutr Biochem. 13:603-610.

Leontowicz, M., Gorinstein ,S., Leontowicz, H., Krzeminski, R., Lojek, A., Katrich, E., Cíz, M., Martin-Belloso O., Soliva- Fortuny, R., Haruenkit, R., and Trakhtenberg, S., 2003: Apple and pear peel and pulp and their influnce on plasma lipids an antioxidant potentials in rats fed cholesterol-containing diets. J Agric Food Chem. 51:57805785.

Lisinska, G., and Leszczynski, W. 1987: Potato tubers as raw materials for processing and nutrition.Ch 2.In G. Lisinska and W. Leszczynski (Eds.), Potato science and technology (pp.34 - 38).London, England: Elsevier Applied Science.

Liu, G. T., Zhang, T. M., and Wang Y. W., 1992: Protective actions of seven natural phenolic compounds against peroxidative damage to biomenbranes, Biochem. Pharmacol. 43-147-152.

Mayr, U., Treutter, D., Buelga, S., Bauer, H., and Feucht, W., 1995: Developmental changes in the phenol concentrations of Golden Delicious apple fruits and leaves. Phytochemistry 38, 1151, 1155.

McGhie, T. K., Hunt, M., and Barnet, L. E., 2005: Cultivar and growing region determine the antioxidant polyphenolic concentration and composition of apples grown in New Zealand. J. Agric. Food Chem.53, 3065 3070 .

Nadeen, M.C.; Dandiya, K.V.; Pasha, M.; Imran, D.K.; Balani, S. B. and Vohora., 1996: Hepatoprotective activity of solanum nigrum fruits. Fitoterapia., 68 (3), 245-251.

Nandita S., and Rajini P.S., 2003: Free radical scavenging activity of an aqueous extract of potato peel ,Food Protectants and Infestation Control Dept., Central Food Technological Research Institute, Mysore 570 013, India. 
Nandita S., and Rajini P.S., 2004: Free radical scavenging activity of an aqueous extract of potato peel, Food Chemistry 85 , 611-616.

National research council, 1996: carcinogens and anticarcinogens in the human diet, wahington: National Academy press.

Onyencho S.N. and Hettiarachchy, N.S., 1993: Antioxidant activity; fatty acids and phenolic acids composition of potato peels. Journal of Science Food \& Agriculture 62: 345-350.

Parmar, H.S., and Kar, A., 2009: Comparative analysis of free radical scavenging potential of several fruit peel extracts by in vitro methods. Drug Disc Ther. 3:49-5

Petkovsek, M.M., Stampar, F., and Veberic, R., 2007: Parameters of inner quality of the apple scab resistant and susceptible apple cultivars (Malus domestica Borkh.). Sci. Hort.114, 37 -44.

Pupsa, R. S.; Connie, M. W. and April, C. M., 1994: Mineral bioavailability in rats from intrinsically labeled whole wheat flour of various phytate levels. J. Agric. Food Chem., 42 (11): 2531-2535

Reitman, S. and Frankel, S. 1957: Clin Path Am. J.,28, 57-63.

Renard, C. M. G. C., Dupont, N., and Guillermin, P., 2007: Concentrations and characteristics of procyanidins and other phenolics in apple during fruit growth. Phytochemistry 68, $1128-1138$.

Rice-Evans, C.A., Miller, N.J., and Paganga,G., 1997: Antioxidant properties of phenolic compounds. New Trend Plant Sci. Rev. 2, 152 -159.

Richmond, W., 1973: Estimation of free and etherified tissue cholesterol. Clinical Chemistry 19: 1350- 1354.

Robards, K., Prenzler, P. D., Tucker, G., Swatsitang, P., and Glover, W., 1999: Phenolic compounds and their role in oxidative processes in fruits. Food Chem. 66, 401 - 436.

Rodriguez de Sotillo, D., Hadley, M., and Holm, E.T.1994b: Potato Peel waste: stability and antioxidan activity of a freeze-dried extract. Journal of Food Science, 59, 1031 - 1033.

Rodriguez de Sotillo,D., Hadley, M., and Holm, E. T.1994a: Phenolics in aqueous potato peel extract: extraction, identi .cation and degradation. Journal of Food Science, 59, 649 - 651.

Sarhan M.A. , Mohdaly A.A., Smetanska I.and Mahmoud A., 2010: Antioxidant properties of various solvent extracts of potato peel, sugar beet pulp and sesame cake. J Sci Food Agric. 30;90(2):218-26.

Singh, A., Sabally, K., Kubow, S., Danielle, J. D., Gariepy, Y., Orsat, V., and Raghavan, G.S.V., 2011: Microwave-Assisted Extraction of Phenolic Antioxidants from Potato Peels, journal, molecules Article 16, 22182232.Food Science, 59, 649 - 651. 
Solovchenko, A., and Schmitz-Eiberger, M., 2003: Signi. cance of skin flavonoids for UV- B-protection in apple fruits.J.Exp.Bot.54,1977 1984.

Sümbüloglu K, Sümbüloglu V: Biyoistatistik, 1998: 8thedition, Hatiboglu Yayinevi, Ankara, p. 76-86.

Treutter, D., 2001: Biosynthesis of phenolic compounds and its regulation in apple. Plant Growth Regul. 34, 71-89.

Trinder, P. 1969: Ann Clin Biochem 6-24.

Tsao, R., Yang, R., Young, J.C., and Zhu, H., 2003: Polyphenolic profiles in eight apple cultivars using high-performance liquid chromatography (HPLC). J. Agric. Food Chem. 51, 6347-6353.

Tsao, R., Yang, R., Xie, S., Sockovie, E., and Khanizadeh, S., 2005: Which polyphenolic compounds contribute to the total antioxidant activities of apple? J. Agric. Food Chem.53, 4989 - 4995.

Valdenegro M., Henríquez, C., Lutz, M., Almonacid S ., Simpson, R., 2010: Development of an Ingredient Containing Apple Peel, as a Source of Polyphenols and Dietary Fiber. Journal of Food Science, 75, (6): H172-H181.

Van der Sluis, A., Dekker, M., d., Jager, A., and Jongen, W. M.F., 2001: Activity and concentration of polyphenolic antioxidant in apple:effect of cultivar, harvest year, and storage conditions. J. Agric. Food Chem. 49, 3606, 3613.

Veberic, R., Trobec, M., Herbinger, K., Hofer, M., Grill, D., and Stampar, F., 2005: phenolic compounds in some apple (Malus domestica Borkh)cultivars of organic and integrated production.J.Sci.Food Agric.85,1687 -1694.

Wang S.Y. and Jiao, H., 2000: Scavenging capacity of berry crops on superoxide radicals, hydrogen peroxide, hydroxy radicals and singlet oxygen, Journal of Agricultural and Food Chemistry 48: 5677-5684.

Wolfe, K. L., Kang, X., He, X., Dong, M., Zhang, Q., and Liu, R. H., 2008:

Cellular antioxidant activity of common fruits. J. Agric. Food Chem.56, 8418 - 8426.

Wolfe, K., and Wu, X., and Liu, R.H., 2003: Antioxidant activity of apple peels. J. Agric. Food Chem. 51, 609 - 614.

Wolfe, K., L., and lui, R. H. 2003: Apple peels as avaluc- added food ingredient. Jouranal of Agri. And Food Chemisitry, 5I, 1676 - 1683.

Yamaguchi, T., Takamura, H., Matoba, T. and Terao, J. 1998: HPLC method for evaluation of the free radical-scavenging activity of foods by using 1, 1,-diphenyl-2-picrylhydrazyl. Bioscience Biotechnology Biochemistry, 62, 1201 -1204. 


\section{التأثير الوقائي لقشور البطاطس والتفاح على الكبد كمضادات أكسدة في الفئران المسيميمة برابع كلوريد الكربون}

$$
\text { اماني احمد عبد القادر سلو }
$$

قسم الاقتصاد المنزلي- كلية التربية النوعية- جامعة المنصورة

الهدف من البحث هو تقييم قشور البطاطس والتفاح كمعطي للمركبات فينولية ودراسة

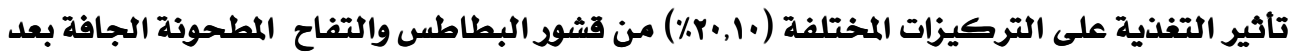

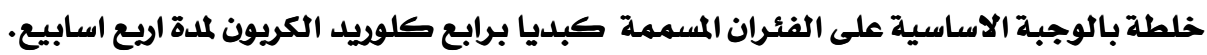

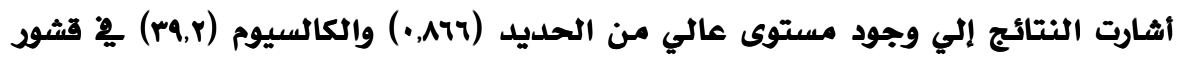

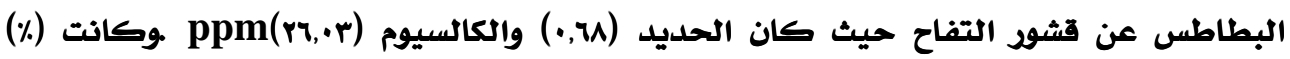

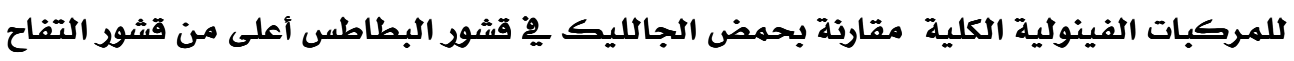
( r,o Vr r,r)

ولوحظ وجود انخفاض معنوي يِ مستوى الكوليسترول الكلي يْ مجموعات الفئران المصابة

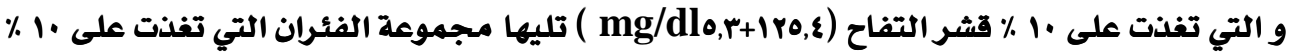

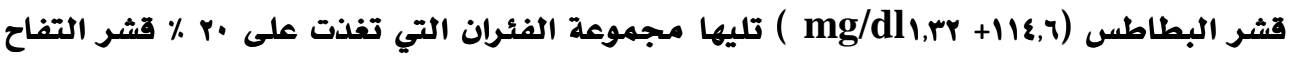

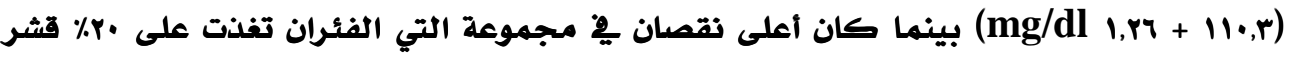

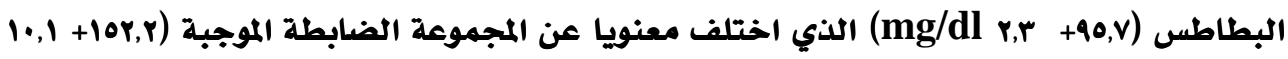

.(mg/dl

التغذية على قشور البطاطس والتفاح بتركيز •r٪ پْ الوجبة الاساسية ِِ مجموعات

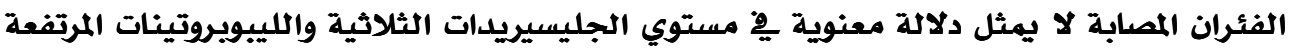

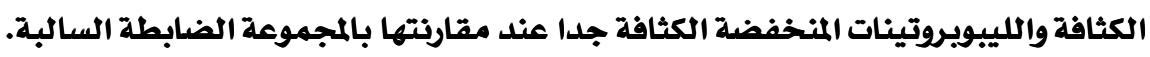

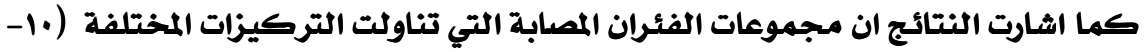

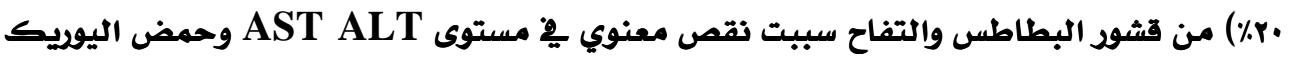

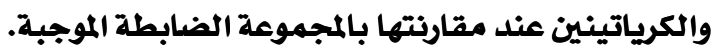

